COPYRIGHT 2003 AFR. J. CLIN. EXP. MICROBIOL

\title{
FUNGAL INFECTIONS IN JOS: A 9-YEAR STUDY
}

\author{
'Ayanbimpe, G.M., ${ }^{2}$ Enweani, I. B., 'Solomon, E.G., \\ 'Department of Medical Microbiology, University of Jos, P.M. B 2084, Jos, Nigeria. \\ ${ }^{2}$ Department of Microbiology and Parasitology, \\ Ambrose Alli University Ekpoma, P.M.B. 14. Ekpoma, Edo State. \\ Correspondence to: Mrs. G. M. Ayanbimpe
}

\begin{abstract}
The prevalent mycoses and their aetiologic agents were studied in 1,287 patients in Jos and environs. $917(71.3 \%)$ of the study population were infected. A male preponderance was observed and the age groups 11-20 and 21-30 were predominantly infected. The most frequently isolated aetiologic agent was Candida spp and the commonest site of infection was the trunk. Unusual'dissemination of lesions caused by Trichosporon beigelii infections was observed. The seasonal occurrence of mycoses and the effect on prevailing aetiologic fungi was studied.
\end{abstract}

\section{INTRODUCTION}

Fungal infections have, in the recent past, received greater recognition from various parts of the world, especially with the upsurge of several fungal pathogens. This upsurge has been attributed to factors such as immunodeficiency, the use of invasive devices or procedures, indiscriminate administration of broad-spectrum antimicrobial agents, which make the individual susceptible to even the otherwise non-pathogenic fungi (1-4). Some persons are at increased risk of susceptibility to infection because of their geographical location, level of health care delivery and ignorance (5-6).

In Nigeria, the most commonly encountered mycoses include superficial and cutaneous infections, but very ew reports are available from some parts of the country on the epidemiology of these infections. Focus in the
Northern Nigeria on mycoses has been on occupational groups, particularly on the Jos Plateau where mining is a major occupation (7).

The present report highlights the types and some aspects of epidemiology of mycoses in Jos, Plateau State, in the past 9 years.

\section{MATERIALS AND METHODS}

The sample population was made up of 1,287 patients, 690 males and 597 females, referred to the Mycology Laboratory of the Medical Microbiology Department of the University of Jos, from the Jos University Teaching Hospital, private clinics, the primary healthcare units within Jos and adjoining local settlements, between January 1991 to December 1999.

Personal data on sex, age, occupation, domicile, recreational activities and salient features of the lesions were recorded. Samples of 
skin scrapings, hair, nail clippings, vaginal, wound and ear swabs, diarrhoeic stool and biopsy specimens were analyzed.

A portion of each specimen was examined under the light microscope, in $20 \%$ potassium hydroxide mount. Cultures of the specimens were also made on slopes of Sabouraud's Dextrose Agar supplemented with chloramphenicol $(0.05 \mathrm{mg} / \mathrm{ml})$ and cycloheximide $(0.5 \mathrm{mg} / \mathrm{ml})$.

Cultures were incubated at room temperature $\left(25-30^{\circ} \mathrm{C}\right)$ for one to six weeks, examined regularly for fungal growth. The yeast isolates were further subjected to a battery of biochemical and physiological tests to identify them to specific levels. Isolates identification was achieved by comparison with standard descriptions in books and manuals $(8-10)$.

\section{RESULTS}

Of the 1,287 patients, 917 (71.3\%) had fungal infections (Table 1). A mean yearly increase in incidence rate of $7.04 \%$ was recorded. Of the positive cases, $502(54.7 \%)$ were males while 415 (45.3\%) were females. There was a male preponderance of infection, generally. Of the 690 male subjects, $502 \quad(72.9 \%)$ were infected while $415(69.3 \%)$ of the 597 females were infected. The predominantly infected age groups were the $21-30(24.0 \%)$ and 11 -
20 (20.0\%) (Fig. 1). The overall number of infected adults was higher than children.

The fungal lesions were found in various parts of the body, most commonly the trunk and multiple sites (Fig.2). Only four samples of tissue biopsy were analyzed and all yielded positive fungus cultures.

The most frequently encountered aetiologic agents over the nine year period are presented in Fig.3. Yeasts and yeast-like fungi predominated followed by dermatophytes with $444 \quad(48.7 \%)$ and $392(42.7 \%)$ isolates, respectively. Candida spp (69.0\%) and Trichophyton mentagrophytes $(41.9 \%)$ out numbered the yeast and dermatophyte isolates, respectively, in occurrence. Of the Candida isolates, C. albicans predominated.

Aspergillus fumigatus formed majority of the hyaline hyphomycetes and more than $70 \%$ was isolated from respiratory infections. Wangiella dermatitidis was the predominant dematiaceous fungus with $11(31.4 \%)$ of the 35 isolates.

The mean monthly rate of infection in the population is shown in Fig. 4, the highest being in August $(14.2 \%)$ and the lowest in December (4\%). A striking observation here was the high occurrence of Trichosporon beigelii in the population, the lesions of which were frequently generalized. 
Table 1: Incidence of Mycoses in the population

\begin{tabular}{|c|c|c|c|c|c|}
\hline \multirow[t]{2}{*}{ Year } & \multirow{2}{*}{$\begin{array}{l}\text { No. } \\
\text { sampled }\end{array}$} & \multicolumn{2}{|c|}{ No. infected } & \multirow[t]{2}{*}{ Total } & \multirow[t]{2}{*}{$\%$} \\
\hline & & Male & Female & & \\
\hline 1991 & 232 & 51 & 39 & 90 & 38.8 \\
\hline 1992 & 98 & 23 & 27 & 50 & 51.0 \\
\hline 1993 & $\overline{83}$ & 30 & 23 & 53 & 63.8 \\
\hline 1994 & 83 & 32 & 16 & 47 & 56.6 \\
\hline 1995 & 112 & 57 & 34 & 91 & 81.2 \\
\hline 1996 & 123 & 51 & 51 & 102 & 82.9 \\
\hline 1997 & 197 & 83 & 90 & 173 & 87.3 \\
\hline 1998 & 179 & 90 & 66 & 157 & 87.1 \\
\hline 1999 & 180 & 85 & 69 & 154 & 85.5 \\
\hline Total & 1287 & 502 & 415 & 917 & 71.3 \\
\hline
\end{tabular}

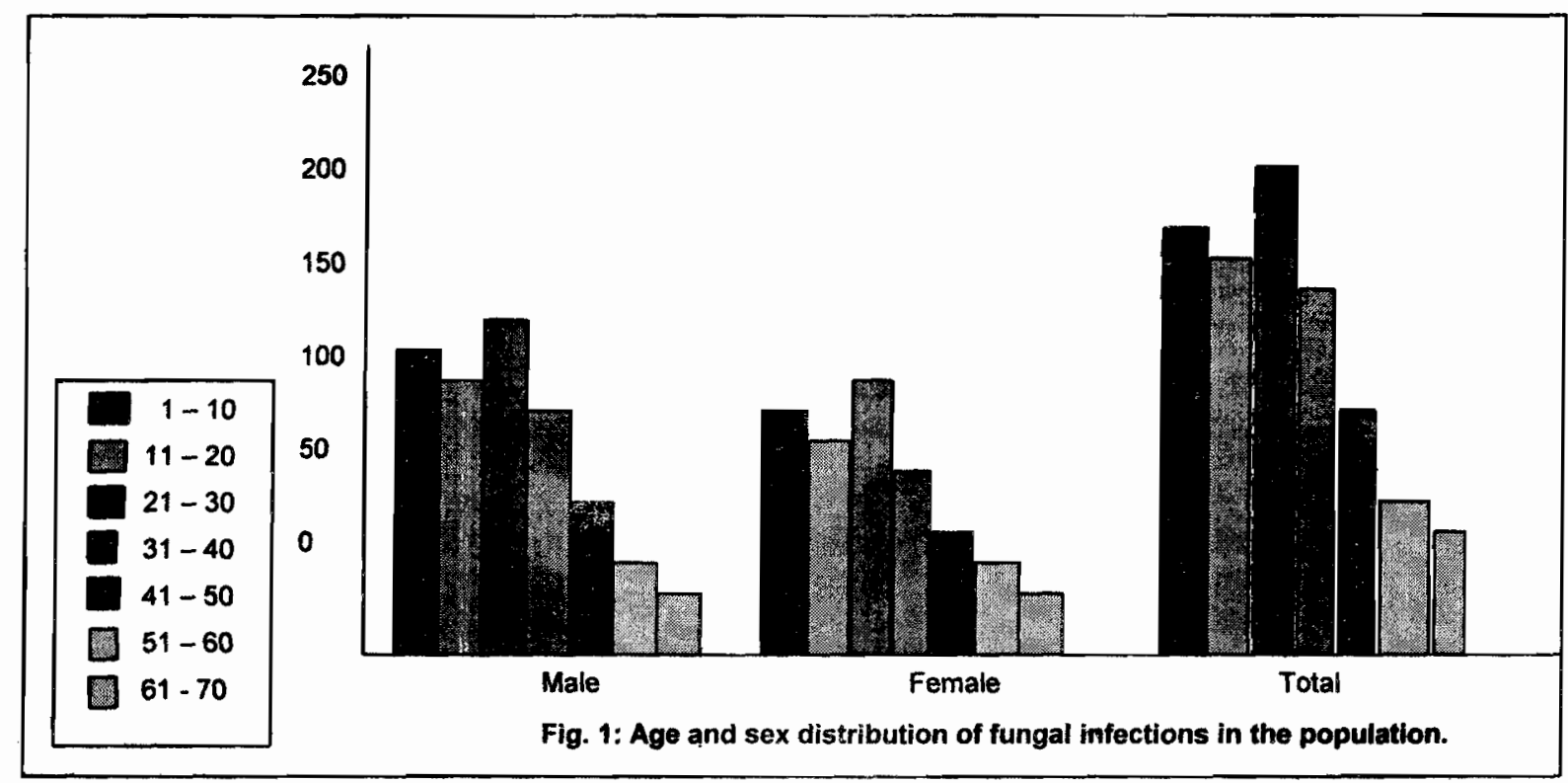




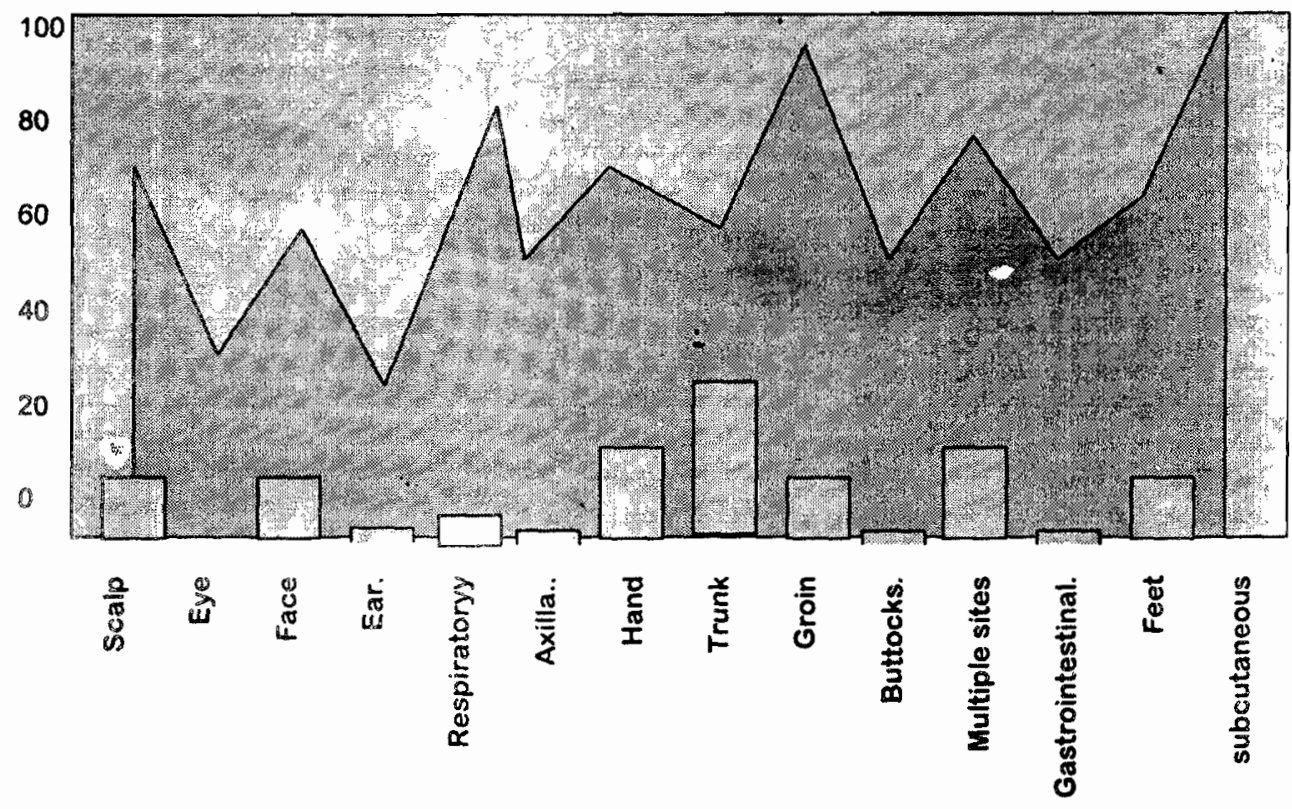

Fig. 2: Distribution of Fungal Infections according to Site of Lesions $\lg .5$ 


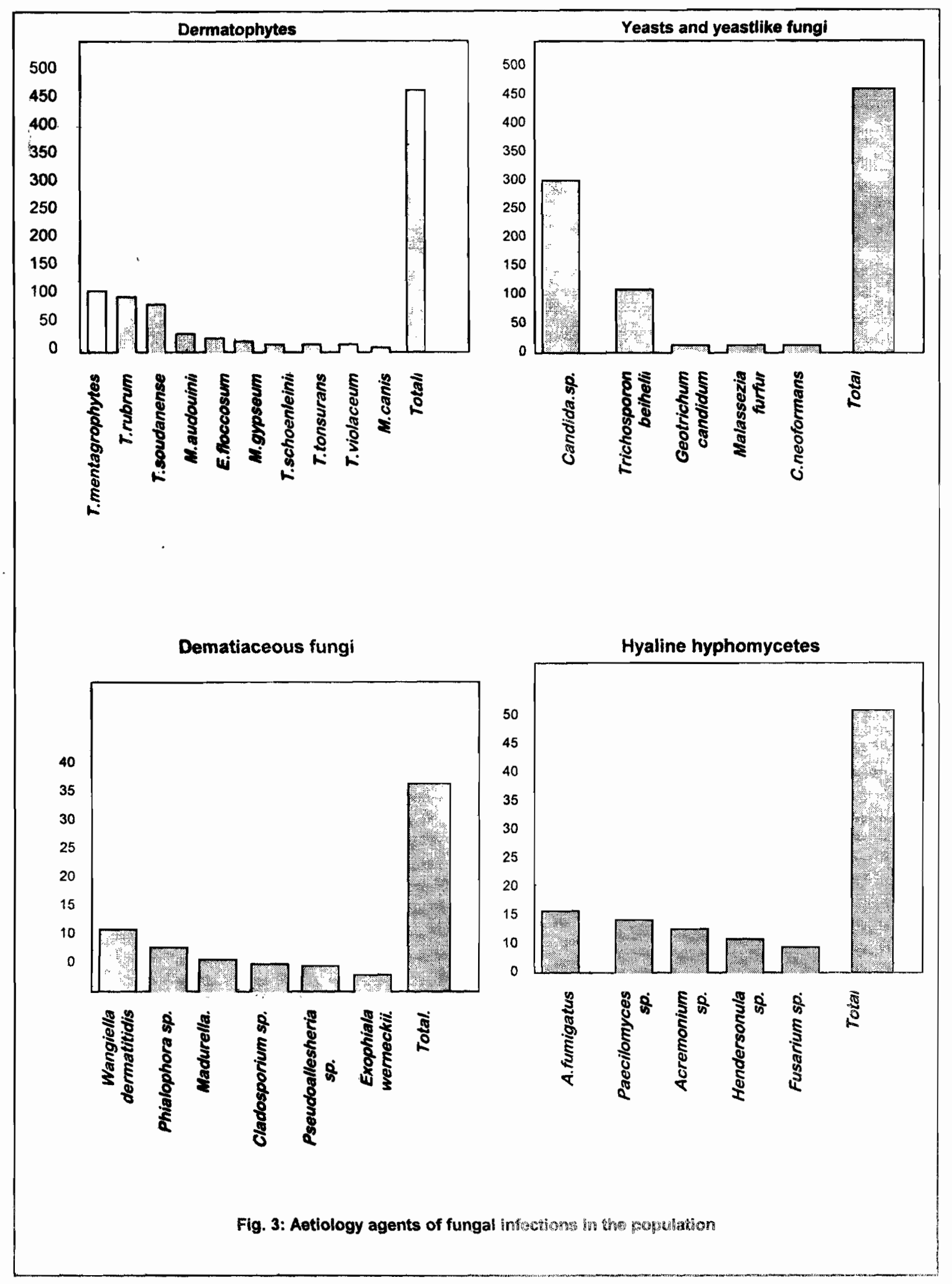

Pg. 6 


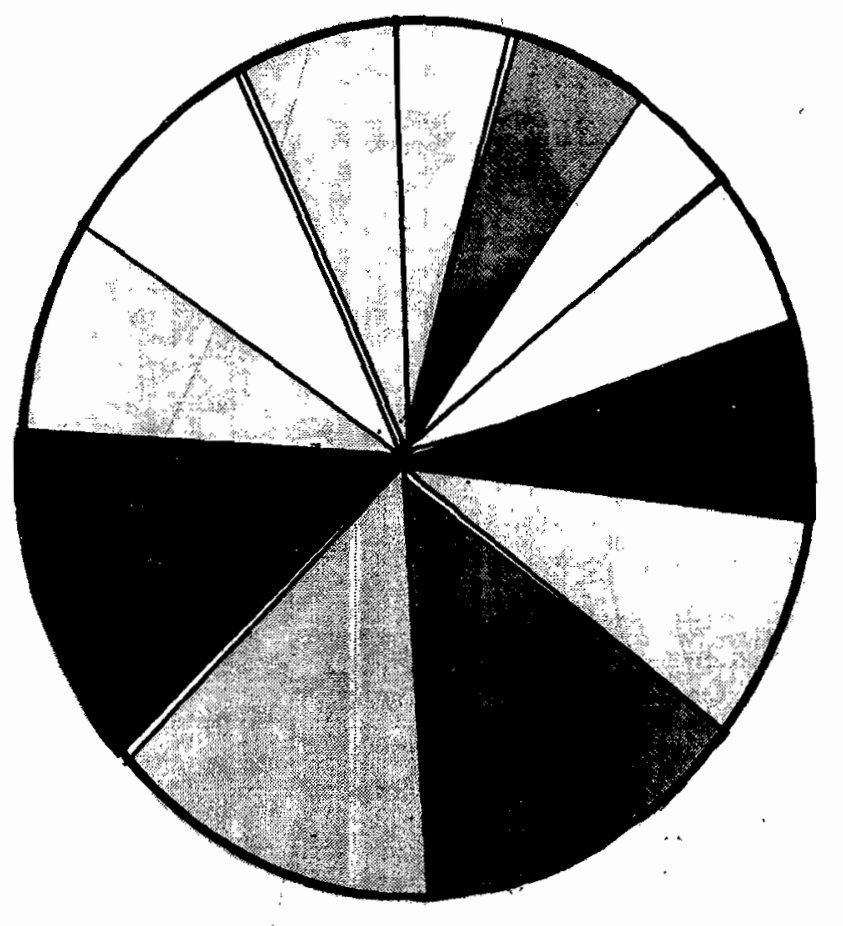

\begin{tabular}{|l|}
$\square$ January \\
February \\
$\square$ March \\
$\square$ April \\
May \\
$\square$ June \\
$\square$ July \\
$\square$ August \\
$\square$ September \\
$\square$ October \\
$\square$ November \\
$\square$ December \\
\hline D
\end{tabular}

Fig. 4: Monthly Incidence of Mycoses in the Population Pg. 7 


\section{DISCUESTI}

This study has revealed the increasing prominence of fungal infections as have been documented from other parts of the world (1-4). Over the years a significant increase was observed in the rate of occurrence of these infections. Some reports $(2,3)$ have revealed that more stressors and factors of immunocompromise have contributed a lot to this trend. Although the present study did not investigate such factors, they may not be far from affecting the present population. More males were infected than females, similar to observations elsewhere within the country (12). Reports from parts of the world, however suggest an equal male - female ratio. This might not be unrelated to the life style of the citizens of Jos, and other parts of Nigeria where males are more exposed to outdoor sources of fungi such as recreational areas and engagement in mining activities.

The predominantly infected age groups, i.e. 21-30 and 11-20 years, include the most active in the populations both at work and play, hence their closer contact with sources of fungal pathogens. Also some these youths are completely ignorant of measures for prevention and control of fungal infections, and the living conditions in boarding schools and hostels where majority resides, favour the spread of mycotic infections. Positive lesions were obtained from various parts of he body, especially the trunk. This was most commonly ringworm infections (tinea corporis), in agreement with the findings of $\mathrm{Al}$ sogar et al (10) in Saudi Arabia, and Egere and Gugnani, in Eastern Nigeria. Little is done in our laboratory on diagnosis of systemic mycoses because of limited resources, but the few tissue biopsies analyzed in this study yielded positive results. This is an important need for consideration by the authorities concerned.

Yeasts were predominant as causative agents of mycoses in this study. Candida species were the most frequently isolated, contrary to reports in Eastern Nigeria and some tropical countries. Trichosporon beigelii, as a single species was isolated in considerably high numbers. A number of investigators have highlighted the increasing importance of this organism, both in immunosuppressed and immuno-competent individuals. The generalized lesions of this organism in a significant number of apparently immunocompetent subjects in this study seems to buttress the reports of other workers elsewhere $(1,13)$.

The predominant dermatophyte species isolated was Trichophyton mentagrophytes, in contrast to the reports from the 
southern parts of the country, and other places $(10,12)$. Also the aetiologic agents in this study are at variance with those obtained in a number of reports. There could be climatic influence on the aetiology of mycoses, as suggested by some workers. The month of August recorded the highest number of infections, contrary to other reports (10) where the hot and dusty weather was suggested to promote spread of mycoses. In Jos the rains are relatively heavy in August and the atmosphere almost dust free. Probably because of the warmth and moisture obtained in this period, the development of fungal pathogens is favoured. The lowest infection rate was recorded in December in this stury the is one of the coldest months in the year here, exposure to outdoor activities like farming and swimming is minimal. This report seems to be the first to consider effects of seasonal variation on mycoses and their aetiologies in Northern Nigeria.

\section{ACKNOWLEDGEMENT}

We thank the Almighty God for the success of this work. Our sincere appreciation also goes to Mr. Yohanna Mato and Mrs Satya Noma, both laboratory assistants in the Mycology laboratory. Mrs. P Anele and Mr. Solomon Danladi for secretarial assistance.

\section{REFERENCES}

1. Ellis DH. Opportunisic Fungi Pose Growing Threat. Mycology Forum. $1995 ; \mathbf{2}(1)$ : 2-7.

2. Jarvis WA. Epidemiology of Nosocmial Fungal Infections, with Emphasis on Candida species. Clin. Infect. Dis. 1995 ; 20 : 15261530 .

3. ridkin SK, Jarvis WR. Epidemiology of Nosocomial Fungal Infections Clin.Microbiel. Rev. 1996 ; 9(4): 499-511.

4. Elewski BE, Greer DL. Hendersonula toruloidea and Scytallidium hyalinum. Review and update. ArchDematol. 1991 ; 127(7) : 1041-1044.

5. McCouy CW, Boucias DG. Selection of Beauvaria bassiana pathotypesas potential microbial control agents of soil-inhabiting citrus weavils. Mems. Inst. Oswalso Cruz. $1989 ; 84$ : 75-80.

6. Ajello L. Ecology and epidemiology of hydrophillic infectious fungi and parafungi of medical naycologial importance: A new category of pathogens. In: Collier L, Balows A, Sussman M (eds). Topley \& Wilson's Microbiology and Microbial infections. 9th edition. Arnold, London. 1998 : 67 73. 
7. Ayanbimpe GM, Bello CSS, Gugnani HC. The aetiological agents of superficial cutaneous in Jos, Plateau State of Nigeria. Mykoses. 1995 ; 38 : 235237.

8. Larone DH. Medically important fungi: a Guide to Identification 3rd edition. ASM Press, Washington, DC. $1995: 274$.

9. Lennette $\mathrm{EH}$, Balows $\mathrm{A}$, Hausler WJ Jr., Shadomy HJ. Manual of Clinical Microbiology. 4th edition. ASM, Washington, DC. $1985: 500-594$.
10. Al-Sogair SM, Moawad MK, Al-Humaidan YM. Fungal infections as a cause of disease in the Eastern province of Saudi Arabia: Prevailing fungi and pattern of infection. Mycoses. 1991 ; 34 : 333-337.

11. Frey D, Oldfield RJ, Bridger RC. A Colour Atlas of Pathogenic Fungi. Wolfe Medical Publication Limited, Holland. 1979 : 168.

12. Egere JU, Gugnani HC. Etiology of Dermatophytosis in Eastern Nigeria: A7 Year Study. Mykosen .1982; 25(4) : 178-181.

13. Kulfas LL. Don't overlook $T$. beigelii in disseminated fungaemia. Current Antiinfective. Therapy. 1994 ; $14(1): 7$. 